\title{
Eksistensi koperasi wanita dalam pencegahan feminisasi kemiskinan
}

\author{
Cenny Julitasari Timur*, Inayati Nuraini Dwiputri \\ Universitas Negeri Malang, Jl. Semarang No. 5 Malang, Jawa Timur, Indonesia \\ *Penulis korespondensi, Surel: cennyjulitasaritimur@gmail.com
}

Paper received: 2-1-2021; revised: 23-1-2021; accepted: 30-1-2021

\begin{abstract}
Abstrak
Koperasi wanita merupakan salah satu kegiatan pemberdayaan wanita melalui sektor ekonomi untuk mencegah feminisasi kemiskinan yang berperan penting dan sentral dalam mewujudkan kesejahteraan keluarga. Sebagai soko guru perekonomian yang berasaskan kekeluargaan, koperasi perlu mengadakan evaluasi dan stimulus untuk meningkatkan perkembangannya khususnya dalam tujuannya yaitu menurunkan ketimpangan antar gender. Penelitian ini bertujuan untuk menganalisis gambaran koperasi wanita di Kabupaten Malang. Hal ini dilatarbelakangi bahwa koperasi wanita memiliki jumlah yang terbanyak di Kabupaten Malang dibandingkan jenis koperasi lainnya. Metode pada penelitian ini menggunakan analisis statistika deskriptif dengan menggunakan data sekunder. Hasil penelitian menunjukkan bahwa dari sejumlah 398 koperasi wanita di Kabupaten Malang memiliki rerata jumlah Sisa Hasil Usaha (SHU) yang cukup besar yaitu sebesar Rp.22.903.000, dengan total jumlah anggota sebanyak 37.301 orang. Hasil penelitian menunjukkan bahwa koperasi wanita memiliki peran penting terhadap perkembangan koperasi yang ada di Kabupaten Malang dengan jumlah koperasi terbanyak dibandingkan dengan jenis koperasi lainnya serta berperan pula terhadap perekonomian khususnya dalam pendapatan wanita yang berasal dari pembagian SHU.
\end{abstract}

Kata kunci: Koperasi Wanita; SHU; Kesejahteraan

\section{Pendahuluan}

Pentingnya koperasi sebagai soko guru ekonomi yang berdasarkan atas asas kekeluargaan dan keberadaan koperasi sebagai bagian untuk pendidikan rakyat akan penguatan ekonomi dan moral rakyat terhadap bidang perekonomian hendaknya tetap dikembangkan ke arah yang lebih produktif, sehingga diharapkan dapat meningkatkan taraf perekonomian yang lebih baik, dimana koperasi sendiri dapat mengatasi kebutuhan dasar masyarakat lapisan bawah bahkan mampu menyentuh perekonomian rumah tangga. Selain itu dalam koperasi pula kebutuhan bersama lebih diutamakan daripada keuntungan.

Pada tahun 2016 jumlah koperasi di indonesia mencapai 212,135 unit dengan total anggota sebanyak 15\% dari populasi Indonesia. Namun 30\% koperasi di Indonesia, pasif dikarenakan berbagai penyebab. Kontribusi koperasi terhadap Produk Domestik Bruto (PDB) sendiri diatas $2 \%$ dimana penyerapan pekerja hanya dapat menyerap $0,5 \%$ dari seluruh populasi di Indonesia (Azhari et al., 2017)

Salah satu contoh program unggulan dari pemerintah terhadap koperasi yaitu fasilitasi pendirian 1000 koperasi wanita (Kopwan) oleh Pemerintah Provinsi Jawa Timur melalui Dinas Koperasi dan UMKM , dimana pada pendirian koperasi wanita diberikan dana bantuan untuk modal senilai Rp.25.000.000,- tiap koperasi wanita. Berdasarkan data Pendataan Program Perlindungan Sosial (PPLS) pada 2011, dari 1.230.042 rumah tangga, sebanyak 152.343 atau $12,4 \%$ kepala rumah tangganya adalah perempuan. Perempuan merupakan salah satu unsur masyarakat yang mempunyai peran penting dan sentral dalam ikut mewujudkan 
kesejahteraan keluarga, sudah sepatutnya diberikan kesempatan ekonomi untuk menjamin ketahanan dasar keluarga melalui peningkatan akses termasuk akses terhadap sumber daya ekonomi (Siswoyo, et al., 2012). Selain itu, koperasi wanita merupakan salah satu wadah aktivitas ekonomi di tingkat desa yang memiliki posisi strategis dalam menggerakkan ekonomi lokal karena koperasi wanita mampu memberdayakan kaum perempuan, menumbuhkan wirausaha baru skala mikro dan kecil serta mampu mencegah urbanisasi, serta menciptakan kesejahteraan dan keamanan (Hadi, 2019).

Salah satu pengaruh eksistensi koperasi sendiri yaitu besarnya Sisa Hasil Usaha (SHU) yang dimiliki. Berdasarkan UU No.25 Tahun 1992 tentang Perkoperasian, SHU koperasi merupakan pendapatan Koperasi yang diperoleh dalam satu tahun buku dikurangi dengan biaya, penyusutan dan kewajiban lainnya termasuk pajak dalam tahun buku yang bersangkutan. Untuk meningkatkan SHU yang besar, diperlukan beberapa pertimbangan dari beberapa faktor dari kelembagaan maupun permodalan seperti modal, jumlah anggota, volume usaha, aset serta lama usaha koperasi sendiri. Mengingat pentingnya SHU pula terhadap keberlangsungan hidup koperasi wanita di Kabupaten Malang. Berdasarkan uraian di atas, maka rumusan masalah dari penelitian ini yaitu bagaimana peranan sisa hasil usaha, modal, jumlah anggota, volume usaha, aset koperasi serta lama pendirian pada koperasi wanita di Kabupaten Malang? Dan bagaimana gambaran koperasi wanita di Kabupaten Malang?

\section{Metode}

Penelitian ini menggunakan metode analisis statistika deskriptif, dimana mencakup teknik-teknik pengumpulan, pengorganisasian, peringkasan serta penyajian data kuantitatif dengan tujuan agar pembaca data dapat memperoleh gambaran secara ringkas dan cepat tentang peristiwa yang direpresentasikan melalui data tersebut (Sugeng, 2020). Penyajian data kuantitatif untuk menggambarkan variabel-variabel berupa nilai minimum, nilai maksimum, rata-rata dan juga standar deviasi.

Data pada penelitian ini merupakan jenis data sekunder, dimana menggunakan data keragaan koperasi triwulan I tahun 2020 serta data-data mengenai Koperasi Wanita Kabupaten Malang yang didapat melalui Dinas Koperasi dan Usaha Mikro Kabupaten Malang. Pada data keragaan tersebut dikumpulkan melalui laporan rapat anggota koperasi tiap koperasi wanita yang berada di Kabupaten Malang. Dengan demikian pula, peneliti mengambil keseluruhan koperasi wanita yang aktif di Kabupaten Malang sebagai populasi pada penelitian.

\section{Hasil dan Pembahasan}

Melalui perhitungan maka didapatkan hasil analisis statistik deskriptif terkait dengan beberapa indikator dari sisi kelembagaan dan sisi permodalan yang berasal data keragaan seluruh koperasi wanita triwulan I Tahun 2020 di Kabupaten Malang, sebagai berikut :

Tabel 1. Analisis Statistik Deskriptif

\begin{tabular}{lccccc}
\hline \multicolumn{1}{c}{ Variable } & Obs & Mean & Std. Dev. & Min & Max \\
\hline Modal (Rp.000) & 398 & 128419.9 & 121446.1 & 15000 & 1033663 \\
Jumlah Anggota (jiwa) & 398 & 93.72111 & 94.8366 & 15 & 1390 \\
Volume Usaha (Rp.000) & 398 & 203996.6 & 295860.4 & 2457 & 1827000 \\
Aset koperasi (Rp.000) & 398 & 194376.8 & 247003.3 & 23100 & 1917222 \\
Lama Pendirian (tahun) & 398 & 10.51256 & 2.396175 & 10 & 41 \\
Sisa Hasil Usaha (Rp.000) & 398 & 22902.88 & 113432.1 & 1 & 2207500 \\
\hline \multicolumn{5}{c}{ Sumber: Data Keragaan Koperasi Wanita Kab.Malang Triwulan I Tahun 2020 (diolah) }
\end{tabular}




\subsection{Modal}

Modal koperasi merupakan sejumlah nilai uang maupun barang yang dimiliki serta dikelola oleh koperasi sehingga dapat menghasilkan barang atau jasa sesuai dengan usaha dan kebutuhan anggota serta masyarakat di sekitarnya. Berdasarkan Undang-Undang No. 25 Tahun 1992 tentang perkoperasian menjelaskan jika modal koperasi terdiri dari modal sendiri dan modal pinjaman. Modal sendiri berasal dari simpanan pokok, simpanan wajib, dana cadangan, hibah. Sedangkan pada modal pinjaman berasal dari anggota, koperasi lainnya dan/atau anggotanya, bank dan lembaga keuangan lainnya, penerbitan obligasi dan surat hutang lainnya, dan sumber lain yang sah. Berdasarkan perhitungan, didapatkan nilai rerata modal dari keseluruhan 398 koperasi wanita di Kabupaten Malang sebesar yang cukup besar yaitu Rp.128.419.900,-. Dimana terdapat ketimpangan koperasi wanita dengan modal paling sedikit yaitu berjumlah Rp.15.000.000,-. Sedangkan koperasi wanita dengan modal terbanyak yaitu berjumlah Rp.1.033.633.000,-

\subsection{Jumlah Anggota}

Pada Undang-undang No. 25 Tahun 1992 pula dijelaskan pengertian dari Anggota koperasi yang merupakan pemilik sekaligus pengguna jasa koperasi dimana keanggotaannya dicatat dalam buku daftar anggota. Yang dapat menjadi anggota koperasi yaitu warga negara Indonesia yang memenuhi persyaratan dalam anggaran dasar. Pada jumlah anggota, dari keseluruhan koperasi wanita di Kabupaten Malang yang berjumlah 398 dengan total jumlah anggota 37.301 orang rerata jumlah anggota pada koperasi wanita yaitu sebanyak 94 jiwa. Dimana dari data tersebut pula terlihat ketimpangan, terdapat koperasi dengan total anggota paling sedikit yaitu sejumlah 15 orang sedangkan koperasi wanita yang memiliki anggota paling banyak yaitu sejumlah 1390 .

\subsection{Volume Usaha}

Volume Usaha merupakan total nilai penjualan atau penerimaan dari barang dan jasa pada suatu periode atau tahun buku yang bersangkutan (Sitio \& Tamba, 2001). Perhitungan volume usaha pada 398 koperasi wanita, dapat dilihat pada tabel 1 jika koperasi wanita di Kabupaten Malang memiliki nilai rerata berjumlah Rp.203.996.600,-. Jumlah volume usaha dari koperasi wanita kabupaten malang dengan jumlah paling sedikit yaitu sebesar Rp.2.457.000,- dan jumlah terbanyak yaitu sebesar Rp.1.827.000.000,-

\subsection{Aset Koperasi}

Menurut Peraturan Menteri Negara Koperasi Dan Usaha Kecil Dan Menengah Republik Indonesia No. 04/ Per/ M.KUKM/ VII/2012 tentang Pedoman Umum Akuntansi Koperasi Kementerian Koperasi Dan Usaha Kecil Dan Menengah, Aset merupakan kekayaan yang dimiliki dan dikelola koperasi untuk menjalankan operasional usaha, dapat juga diartikan sebagai sumber daya yang dikuasai koperasi sebagai akibat dari peristiwa masa lalu dan darimana manfaat ekonomi di masa depan diharapkan akan diperoleh koperasi.

Perhitungan aset koperasi menunjukkan jika nilai rerata berjumlah Rp.194.376.800,dengan jumlah terendah aset koperasi yang dimiliki koperasi wanita di Kabupaten Malang sebesar Rp.23.100.000 sedangkan jumlah tertinggi sebesar Rp.1.917.222.000,- 


\subsection{Lama Pendirian}

Lama Pendirian yang dimaksud yaitu jangka waktu koperasi beroperasi dihitung mulai dari waktu pendirian koperasi sampai penelitian dilaksanakan, dimana lama nya koperasi beroperasi dapat memberikan pengalaman sehingga dapat mempengaruhi koperasi dalam melakukan kegiatannya. Rata-rata lama pendirian koperasi wanita di Kabupaten Malang yaitu 10,5 tahun dengan koperasi wanita tertua yang telah berdiri di Kabupaten Malang yaitu 41 tahun, sedangkan koperasi wanita termuda berumur 10 tahun.

\subsection{Sisa Hasil Usaha}

Melalui perhitungan didapatkan rerata SHU dari 398 koperasi wanita di Kabupaten Malang sebesar Rp.22.902.880, dimana koperasi wanita dengan jumlah SHU tertinggi yaitu sebesar Rp2.207.500.000,- sedangkan koperasi wanita dengan jumlah SHU terendah yaitu sebesar Rp.1000,-. Dari perbandingan antara SHU terendah dan tertinggi terlihat jika terjadi ketimpangan pada hasil SHU koperasi wanita di Kabupaten Malang.

SHU dibagikan pada anggota sebanding dengan jasa usaha yang dilakukan oleh anggota setelah dikurangi dana cadangan dimana akan digunakan pula untuk pendidikan perkoperasian dan keperluan lain dari Koperasi sesuai dengan keputusan Rapat anggota. Jasa anggota sendiri diukur berdasarkan jumlah kontribusi masing-masing terhadap pembentukan SHU itu. Ukuran kontribusi yang digunakan adalah jumlah transaksi pembelian anggota kepada Koperasi selama periode tertentu (Baswir, 1997). Meskipun keuntungan bukan tujuan utama dari usaha koperasi namun usaha yang dikelola oleh koperasi harus memperoleh SHU untuk bertahan hidup dan meningkatkan usahanya. Besarnya SHU yang diperoleh suatu koperasi dapat mencerminkan bahwa koperasi tersebut telah dikelola dengan baik dan profesional, sehingga dengan banyaknya keuntungan yang diperoleh anggota koperasi, menjadikan anggota lebih berupaya maksimal untuk mengembangkan koperasinya.

\subsection{Eksistensi Koperasi Wanita}

Pembangunan Koperasi wanita ditujukan untuk mencegah feminisasi kemiskinan yang biasanya terjadi wanita "single parent". Sasaran dari program pendirian koperasi wanita di Jawa Timur tersebut yaitu dapat terwujud peningkatan pada modal kerja bagi perempuan anggota kelompok/koperasi dalam bentuk pinjaman, peningkatan pada pengembangan usaha ekonomi produktif bagi perempuan anggota koperasi, dan juga peningkatan pada taraf hidup keluarga anggota koperasi. Sejak diadakan program pembentukan Koperasi Wanita (Kopwan) di Jawa Timur pada 2009, sampai saat ini tetap menjadi program prioritas yang terus dikembangkan, dimana program tersebut berawal dari implementasi visi Mantan Gubernur Jatim periode 2009-2019 , Dr. H. Soekarwo yaitu "APBD untuk rakyat"

Pendirian koperasi wanita sendiri diprioritaskan untuk kelompok-kelompok yang sudah terkenal di lingkungan masyarakat namun belum memiliki badan hukum koperasi yang diharapkan lembaga-lembaga tersebut berperan besar dalam peningkatan taraf hidup masyarakat desa, misalnya Usaha Ekonomi Desa-Simpan Pinjam (UED-SP), Badan Kredit Desa (BKD), Badan Usaha Kredit Pedesaan (BUKP), Lumbung Pitih Nagari (LPN), Lembaga Perkreditan Desa (LPD), Badan Kredit Kecamatan, Kelompok Usaha Bersama (KUBE), Kelompok Program Peningkatan Pendapatan Petani dan Nelayan Kecil (P4K) dan lain-lain. 
Dari adanya program tersebut, di Kabupaten Malang banyak berdiri koperasi wanita baru yang digambarkan dengan grafik dibawah ini :

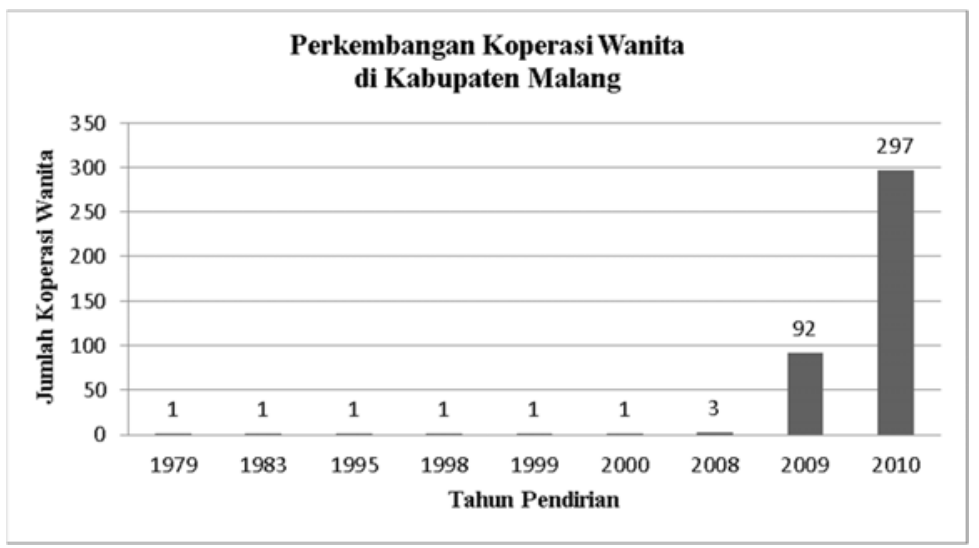

\section{Gambar 1. Perkembangan Koperasi Wanita di Kabupaten Malang \\ Sumber: Data Keragaan Koperasi Wanita Kab.Malang Triwulan I Tahun 2020 (diolah)}

Pada tahun 2009 telah berdiri koperasi wanita sebanyak 92 dan pada tahun 2010 semakin meningkat jumlah dari koperasi wanita dengan berdirinya 297 koperasi. Salah satu bentuk strategi dari penguatan koperasi dapat melalui pendekatan cluster atau pengembangan sentra-sentra bisnis dan/atau pendekatan inkubator (Tanjung, 2017). Adapun peran dari Dinas Koperasi dan Usaha Mikro Kabupaten Malang terhadap koperasi wanita yang bertujuan untuk menurunkan tingkat kemiskinan di Kabupaten Malang yaitu sebagai berikut: (1) Pada bidang kelembagaan dan pengawasan koperasi terdapat program sosialisasi perkoperasian dan bimbingan teknis perkoperasian, dimana sosialisasi tersebut ditujukan bagi kelompok ekonomi produktif (KEP), lalu diadakan bimbingan teknis perkoperasian bagi koperasi serta pemberian penghargaan koperasi bagi koperasi yang berprestasi. (2) Pada bidang produksi dan pemasaran koperasi melalui koperasi wanita mengikuti pameran produk koperasi tingkat regional dan nasional, serta pengadaan bimbingan teknis inkubator teknologi dan bisnis serta diversifikasi usaha produk koperasi.

Umumnya koperasi wanita di Kabupaten Malang merupakan jenis koperasi konsumen dengan sektor usahanya di bidang ekonomi, dimana koperasi wanita menghasilkan produk dengan memanfaatkan potensi daerahnya masing-masing. Dimana pada tahun 2020, di Desa Bringin, Kecamatan Wajak terdapat dua koperasi wanita yaitu Koperasi Wanita Ringin Asri dan Koperasi Simpan Pinjam Pola Syariah Desa Bringin yang memanfaatkan olahan produk hasil pertanian daerahnya yaitu ubi dan singkong menjadi carangmas dan dodol tape singkong. Daerah tersebut mayoritas penduduknya bekerja pada sektor pertanian dan perkebunan. Dengan adanya Pandemi Covid-19, koperasi wanita bersama Dinas Koperasi dan Usaha Mikro Kabupaten Malang mengadakan pelatihan via online untuk mengurangi kerumunan masa dengan jumlah tertentu. Pelatihan tersebut menggunakan sistem TOT (Training Of Trainers), dimana peserta pelatihan berjumlah 50 orang yang dibagi menjadi 10 kelompok dan selanjutnya pada masing-masing kelompok akan diambil 1 orang. Satu orang tersebut akan dilatih bersama praktisi/narasumber secara langsung. Orang-orang pilihan tersebut nantinya akan mempraktekkan pada kelompoknya masing-masing. Materi yang disampaikan antara lain yaitu pemilihan bahan baku, alat, pembuatan, cara pengemasan serta pemasaran produk. Program tersebut diharapkan dapat meningkatkan kualitas wanita yang selanjutnya akan meningkatkan pendapatan masyarakat, mengurangi pengangguran, menurunkan tingkat 
kemiskinan, memperbaiki pemerataan pendapatan masyarakat, selain itu dampak dengan adanya pelatihan tersebut yaitu pengelolaan koperasi sesuai dengan nilai-nilai dan prinsipprinsip koperasi dapat meningkatkan perkembangan dan pertumbuhan koperasi secara sehat dan pembentukan wadah organisasi koperasi untuk meningkatkan efisiensi usaha koperasi. Sehingga secara tidak langsung koperasi wanita berdampak pada sosial ekonomi masyarakat Kabupaten Malang.

\section{Simpulan}

Perhitungan indikator koperasi wanita dari sisi kelembagaan dan sisi permodalan menunjukkan jika rata-rata terhadap modal sebesar Rp.128.419.900, jumlah anggota sebanyak 98 orang, volume usaha sebesar Rp.203.996.600, aset koperasi sebesar Rp.194.376.800, lama pendirian memiliki rerata 10,5 tahun dan Sisa hasil usaha sebesar Rp.22.902.880. Dari perhitungan modal, jumlah anggota, volume usaha, aset koperasi, lama pendirian dan sisa hasil usaha pula terdapat ketimpangan pada jumlah terendah dan tertinggi pada modal, jumlah anggota, volume usaha, aset koperasi dan sisa hasil usaha. Dengan adanya ketimpangan tersebut, maka dinas koperasi maupun koperasi wanita sendiri mengadakan beberapa program sosialisasi serta bimbingan yang tujuan utamanya yaitu untuk menurunkan tingkat kemiskinan melalui wadah koperasi wanita tersebut. Pada Dinas Koperasi dan Usaha Mikro Kabupaten Malang, mengadakan program sosialisasi perkoperasian dan bimbingan teknis perkoperasian bagi kelompok ekonomi produktif (KEP), pemberian penghargaan koperasi bagi koperasi yang berprestasi, mengikutsertakan koperasi wanita pada pameran produk koperasi tingkat regional dan nasional dan bimbingan teknis inkubator teknologi dan bisnis serta diversifikasi produk koperasi.

Mengingat adanya ketimpangan terutama pada sisa hasil usaha yang merupakan faktor yang mempengaruhi keberlangsungan hidup koperasi wanita, diperlukan kesinambungan antara pemerintah dan koperasi wanita sendiri terhadap program-program yang diadakan. Bagi pemerintah, diperlukan perhatian khusus pada koperasi wanita yang dinilai kurang pada sisi kelembagaan maupun sisi permodalan untuk mencegah adanya koperasi pasif. Bagi koperasi wanita di Kabupaten Malang, agar memaksimalkan kegiatan pelatihan, bimbingan serta teknologi yang diharapkan dapat dipraktekkan agar dapat mengembangkan usahanya tidak hanya menjadi koperasi konsumen namun juga koperasi produksi sehingga dapat meningkatkan pendapatan, sehingga secara tidak langsung koperasi wanita diharapkan berdampak pada sosial ekonomi masyarakat Kabupaten Malang. Serta bagi koperasi wanita di luar Kabupaten Malang, dapat menjadikan koperasi wanita di Kabupaten Malang sebagai referensi terhadap kegiatan-kegiatan yang dilakukan sehingga diharapkan terdapat peningkatan pada sisi permodalan maupun sisi kelembagaan.

\section{Daftar Rujukan}

Azhari, Syechalad, M. N., Hasan, I., \& Majid, M. S. A. (2017). The Role of Cooperative in the Indonesian Economy. International Journal of Humanities and Social Invention, 6(10), 43-46.

Baswir, R. (1997). Koperasi Indonesia. Yogyakarta: BPFE-Yogyakarta.

Hadi, M. P. (2019). Kemandirian Ekonomi Melalui Koperasi Wanita. Media Info KUMKM edisi I Dinas Koperasi dan UKM Provinsi Jawa Timur. Diakses dari http://diskopukm.jatimprov.go.id/info/media-info-kukm.

Hendar. (2010). Manajemen Perusahaan Koperasi. Jakarta: Erlangga.

Peraturan Menteri Negara Koperasi Dan Usaha Kecil Dan Menengah Republik Indonesia No. 04/ Per/ M.KUKM/ VII/2012 tentang Pedoman Umum Akuntansi Koperasi Kementerian Koperasi Dan Usaha Kecil Dan Menengah 
Jurnal Ekonomi, Bisnis dan Pendidikan, 1(1), 2021, 78-84

Siswoyo, B. B., Djawahir, A. H., Fathorazi, Wuryani, E., zainuri, Hariyati, ... Murdiono, A. (2012). Pengembangan Koperasi Wanita Materi Pendampingan Koperasi Wanita di Jawa Timur. Malang: UM.

Sugeng, B. (2020). Fundamental Metodologi Penelitian Kuantitatif (Eksplanatif). Yogyakarta: Deepublish.

Tamba, H., \& Sitio, A. (2001). Koperasi Teori dan Praktik. Jakarta: Erlangga.

Tanjung, M. (2017). Koperasi dan UMKM sebagai Fondasi Perekonomian Indonesia. Jakarta: Erlangga.

Undang-Undang No. 25 Tahun 1992 tentang Perkoperasian. 